\title{
RANCANG BANGUN APLIKASI MONITORING PEMBERIAN OBAT BAGI PASIEN
}

\author{
Vina Ayumi ${ }^{1}$, Handrie Noprisson ${ }^{2}$ \\ Fakultas IImu Komputer, Universitas Mercu Buana \\ Jl. Raya Meruya Selatan, Kembangan, Jakarta 11650 \\ E-mail: 1 vina.ayumi@mercubuana.ac.id, 2 handrie.noprisson@mercubuana.ac.id
}

\begin{abstract}
In direct control of the drug in each patient, the nurse will spend a lot of time. In addition, the possibilities of errors generally occur frequently. To avoid such mistakes have been designed and made the device used to organize and monitor the administration of drugs in patients. The data collection method used in this research is to use 3 (three) ways of observation, interview, and literature study. System development method that writer use is method of Rapid Application Development (RAD). As a result, this application consists of several classes in the system, among others, nurses, patients, medications, prescriptions and history. This application is expected to assist nurses in controlling patient drug delivery.
\end{abstract}

\begin{abstract}
Abstrak- Dalam melakukan pengontrolan obat secara langsung pada tiap pasien, perawat akan menghabiskan banyak waktu. Selain itu, kemungkinan terjadi kesalahan umumnya sering terjadi. Untuk menghindari terjadinya kesalahan tersebut telah dirancang dan dibuat perangkat yang digunakan untuk mengatur dan melakukan monitoring pemberian obat pada pasien. Adapun metode pengumpulan data yang digunakan dalam penelitian ini adalah dengan menggunakan 3 (tiga) cara yaitu observasi, wawancara, dan studi pustaka. Metode pengembangan sistem yang penulis gunakan adalah metode Rapid Application Development (RAD). Sebagai hasil, aplikasi ini terdiri dari beberapa class dalam sistem antara lain, perawat, pasien, obat, resep dokter dan history. Aplikasi ini diharapkan dapat membantu perawat dalam mengontrol pemberian obat pasien.
\end{abstract}

Keywords- rapid application development (RAD), monitoring application, medication

\section{Pendahuluan}

Perkembangan teknologi komputer (informatika) yang begitu pesat telah merambah ke berbagai sektor termasuk kesehatan, terutama dalam pengembangan aplikasi untuk mendukung kesehatan [1]-[3]. Informatika kedokteran dan informatika keperawatan sebagai bagian dari informatika kesehatan merupakan lingkup bidang terapan multidisiplin dengan fokus pasien atau klien sebagai customer utama yang ditujukan dalam peningkatan pelayanan kesehatan.

Peluang penerapan teknologi informasi dan komunikasi menjadi semakin luas ketika bidang keperawatan dihadapkan kepada tuntutan masyarakat terhadap pelayanan yang berkualitas sehingga para perawat harus menyediakan waktu asuhan langsung (direct care) kepada pasien yang lebih lama dan berkualitas.
Teknologi membantu perawat mengurangi waktu dokumentasi dan mengalihkannya untuk direct care. Mereka menggunakan teknologi dan informatika untuk meningkatkan efektifitas pelayanan keperawatan, keamanan, dan hasil perawatan klien.

Individu yang mengalami sakit membutuhkan obat dalam jumlah dan jenis yang berbeda sesuai dengan penyakitnya. Jumlah dan jenis pemberian obat dalam terapi harus tepat sehingga dapat mencapai efek yang optimal. Rancangan cairan ini disesuaikan dengan kondisi patologis. Pemberian obat yang salah bisa memperberat penyakit pasien. Pemberian terapi obat harus dilakukan dengan prinsip 6 benar yaitu benar nama pasien, jenis cairan, dosis, cara pemberian, waktu pemberian, dan dokumentasi. 
Pengontrolan obat pada tiap pasien secara langsung dan berkala perlu dilakukan oleh perawat agar mencegah terjadinya kesalahan dalam pemberian obat pasien. Akan tetapi, pengontrolan obat secara langsung pada tiap pasien tentunya akan menghabiskan banyak waktu perawat. Selain itu, kemungkinan terjadi kesalahan umumnya sering terjadi. Kesalahan ini dapat menyebabkan kerugian pada pasien dan meningkatkan biaya kesehatan.

Untuk menghindari terjadinya kesalahan tersebut telah dirancang dan dibuat perangkat yang digunakan untuk mengatur dan melakukan monitoring pemberian obat pada pasien. Untuk itu perawat membutuhkan teknologi yang dapat mempermudah kegiatan yang berhubungan dengan pengelolaan pemberian terapi obat kepada pasien yang bersifat mobile. Fitur-fitur yang ada pada smartphone android mampu menjalankan beragam aplikasi sehingga mempermudah pengguna dalam melakukan berbagai aktivitas kehidupan.

\section{Studi Literatur}

Pada bagian ini akan dijelaskan definisi aplikasi dan teori rapid application development.

\section{A. Aplikasi}

Pengertian tentang Aplikasi berasal dari bahasa inggris, yaitu "to applicate" yang artinya menerapkan atau terapan. Namun pengertian mengenai aplikasi secara umum adalah suatu paket program yang sudah jadi dan dapat digunakan. Sedangkan arti aplikasi adalah "program komputer yang dibuat untuk menolong manusia dalam melaksanakan tugas tertentu" [4].

Komputer itu sendiri kaitannya dengan aplikasi yang terdiri dari beberapa unit fungsional untuk mencapai tujuan pelaksanaan pengolahan data yaitu [4]:

a. Bagian yang membaca data (input data atau input unit)

b. Bagian yang mengelola data (control processing unit)

c. Bagian yang mengeluarkan hasil pengolahan data

Selain itu pengertian Aplikasi merupakan satu unit perangkat lunak yang dibuat untuk melayani kebutuhan akan beberapa aktivitas seperti sistem perniagaan game, pelayanan masyarakat, periklanan, atau semua proses yang hampir dilakukan manusia [5]

\section{B. Rapid Application Development}

Menurut [6], Rapid Application Development (RAD) adalah suatu pendekatan desain sistem yang menggunakan teknik terstruktur, prototyping, dan Joint Application Development (JAD) untuk mengembangkan sistem secara tepat. Sedangkan menurut [7], RAD adalah sebuah model proses pengembangan perangkat lunak sekuensial linier yang menekankan siklus pengembangan yang sangat pendek.

\section{Metodologi Penelitian}

\section{A. Metode Pengumpulan Data}

Adapun metode pengumpulan data yang digunakan dalam pembahasan ini adalah dengan menggunakan 3 (tiga) cara yaitu observasi, wawancara, dan studi pustaka.

Pada penelitian ini peneliti melakukan observasi di ruang perawatan Ichsan Medical Center (IMC) Jalan raya Jombang No. 56 Bintaro Sektor 9, Tangerang Selatan. Dalam observasi hal-hal yang dilakukan adalah mengikuti pelayanan kesehatan di ruang pasien bersama perawat dan memantau sistem penjadwalan infus yang berjalan di rumah sakit.

Wawancara dengan pihak terkait guna mendapatkan informasi tentang permasalahan dan kebutuhan aplikasi yang akan dirancang. Pihak yang dimaksud adalah salah satu perawat yang ada di Rumah Sakit IMC Binataro bernama Fikhi.

Untuk mengetahui bagaimana tanggapan atas aplikasi yang dibuat, maka penulis melakukan pengumpulan data dengan menyebarkan kuesioner kepada beberapa responden yaitu perawat di Rumah Sakit IMC Bintaro. Pengambilan sampel dilakukan secara probability sampling (pemilihan random) dengan menggunakan metode simple random sampling, dimana pengambilan sampel anggota populasi dilakukan secara acak tanpa memperhatikan strata yang ada dalam populasi itu.

\section{B. Metode Pengembangan Aplikasi}


Metode pengembangan sistem yang penulis gunakan adalah metode Rapid Application Development (RAD) yang diperkenalkan James Martin pada tahun 1991 yang memiliki tahapan-tahapan berikut [8]:

\section{Fase Perencanaan Syarat}

Dalam tahap ini pihak rumah sakit yaitu perawat dan penulis bertemu untuk mengidentifikasi tujuan-tujuan aplikasi atau sistem serta mengidentifikasi kebutuhan aplikasi yang ditimbulkan dari tujuan-tujuan tersebut.

\section{Workshop Design}

Adapun metode desain yang digunakan terdiri dari beberapa tahapan, yaitu:

a. Perancangan proses yang akan terjadi didalam sistem menggunakan diagram UML.

b. Perancangan spesifikasi proses yang dibutuhkan, dengan menerjemahkan proses-proses yang terjadi di dalam sistem ini ke dalam bentuk algoritma sederhana yang akan diimplementasikan dalam bentuk program.

c. Perancangan interface, dengan membuat rancangan layar tampilan yang berupa input-output yang bertujuan untuk memfasilitasi komunikasi antar user dengan sistem. Setelah rancangan layar tampilan terbentuk maka dilakukan tahap konstruksi.

\section{Fase Pelaksanaan}

Fase pelaksanaan dilakukan dengan implementasi database, instalasi ke handset Android serta melakukan pengujian atau testing aplikasi secara Blackbox.

\section{Hasil dan Diskusi}

\section{A. Fase Perencanaan Syarat}

Pada tahap analisis dilakukan pencarian data dan informasi yang sesuai dengan kebutuhan dari aplikasi juga merancang konsep dari aplikasi dan mencari perangkat lunak yang cocok dengan pembuatan aplikasi. Untuk menyelesaikan pembuatan sistem ini maka dilakukan perancangan terhadap sistem yang akan dibuat. Berikut ini rancangan sistem yang diusulkan seperti yang terlihat pada Gambar 1.

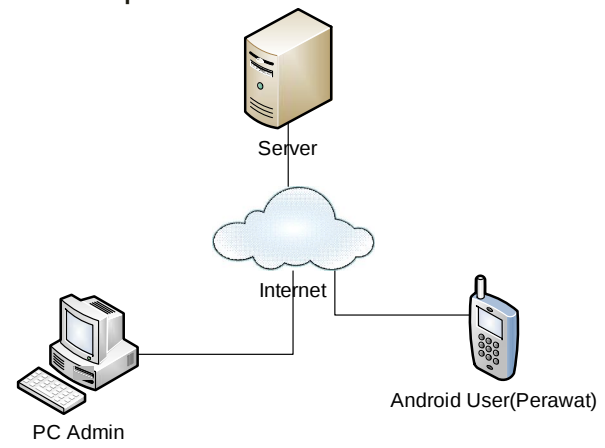

Gbr. 1 Blok Diagram Sistem

Data-data mengenai obat pasien tersimpan di dalam database server. Admin mengakses database melalui web browser pada komputer. Admin dapat melakukan input, edit, delete pada datadata master seperti data perawat, pasien, data obat-obatan, dan data ruangan. Admin dapat melihat laporan perkembangan pemberian obat pasien pada web browser komputer.

Perawat mengakses data tersebut melalui smartphone android. Perawat dapat mengupdate data-data mengenai obat yang dipakai oleh pasien. Perawat terkoneksi langsung dengan database server secara realtime dan sistem akan memberi peringatan kepada perawat apabila infus pasien habis atau pasien harus minum obat. Kelengkapan software yang digunakan:

a. Java Development Kit (JDK 1.6)

b. Eclipse Pulsar Helios

c. ADT versi 0.9 .9

d. Android SDK update platform 2.2 Froyo

e. XAMPPLITE

f. Notepad ++

g. Sistem Operasi Windows 7 Ultimate 32-bit yang berjalan di laptop.

Kelengkapan hardware yang digunakan:

a. Satu buah laptop untuk membuat program dengan spesifikasi sebagai berikut Processor Core 2 Duo T6500 $2.10 \mathrm{GHz}$, Memory $2 \mathrm{~GB}$, Hardisk 250 GB.

b. Monitor dengan resolusi $1280 \times 800$ pixel.

c. Sebuah Kabel Data Android untuk mentransfer file aplikasi dari PC ke Android device. 
d. Smartphone Android Platform 2.2 (Froyo) keatas.

\section{B. Fase Workshop Design}

Dalam perancangan aplikasi ini digunakan model Unified Modelling Languange (UML), use case diagram mendeskripsikan interaksi aktor di dalam sistem aplikasi. Use case diagram pada aplikasi ini terdiri dari dua aktor, yaitu admin, dan perawat.

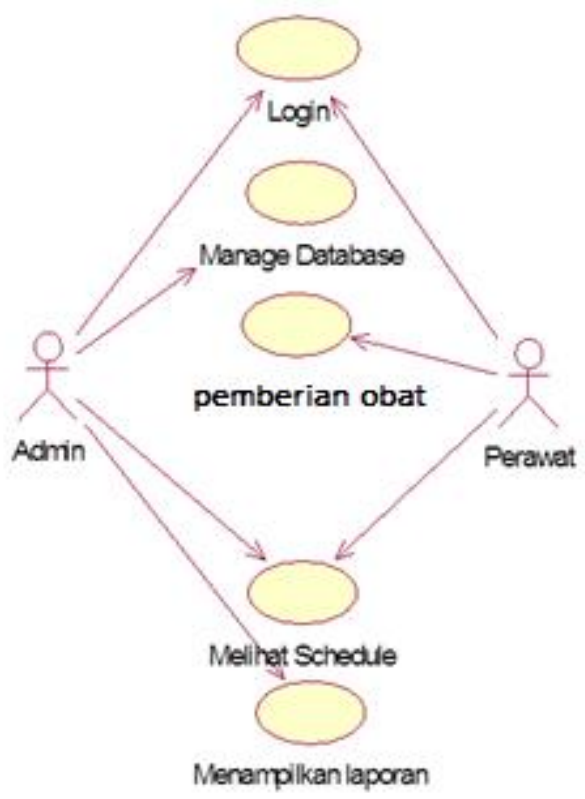

Gbr. 2 Use Case Diagram Aplikasi

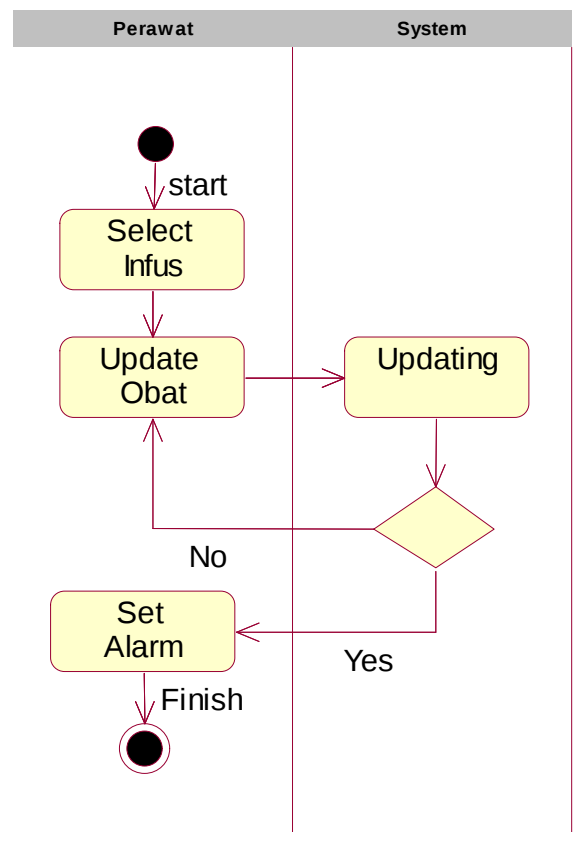

Gbr. 3 Activity Diagram Aplikasi

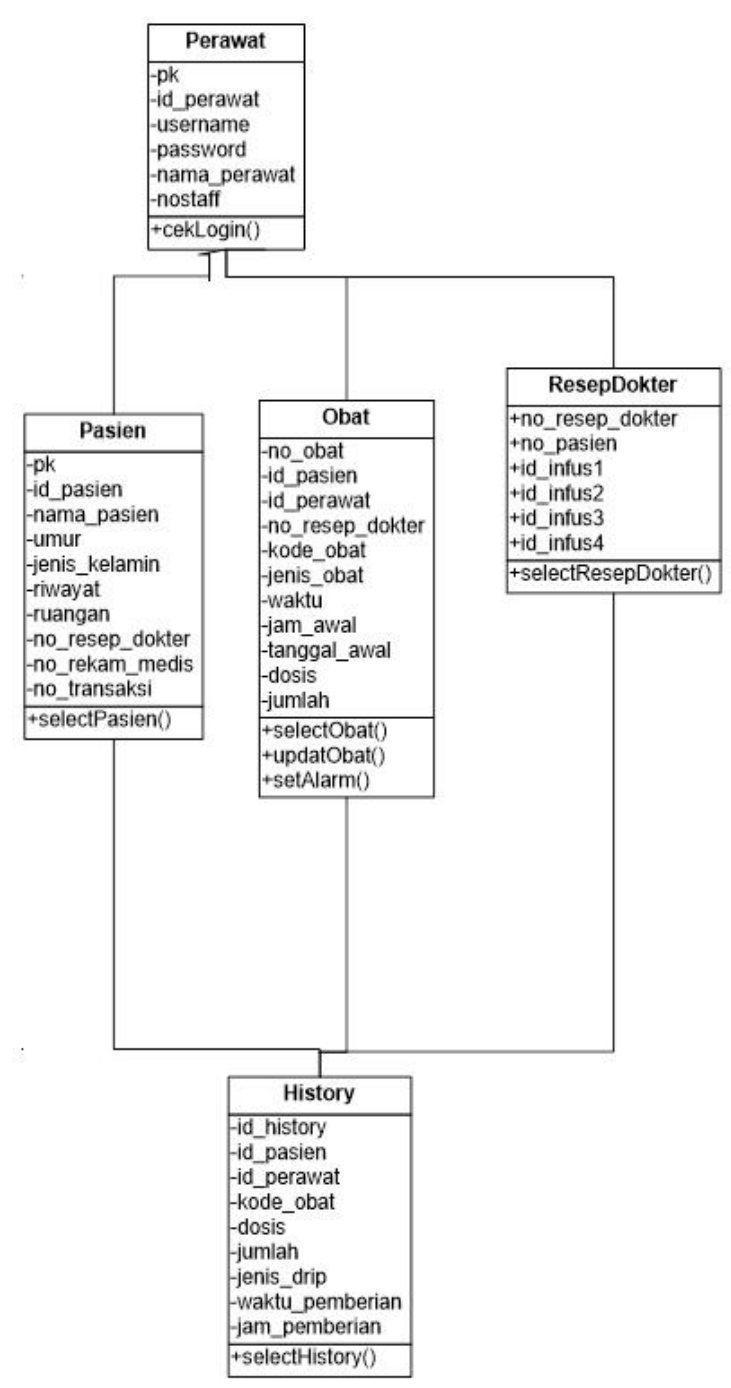

Gbr. 4 Class diagram Aplikasi Android

\section{Fase Pelaksanaan}

Sebelum program diimplementasikan, maka program harus terbebas dari kesalahan-kesalahan.

Kesalahan program yang mungkin terjadi antara lain karena kesalahan penulisan (coding), kesalahan proses, atau kesalahan logika.

Dalam tahap implementasi aplikasi ini, analisis kebutuhan perangkat pendukung menjadi hal yang sangat penting. Sistem ini dapat berjalan dengan baik, apabila mampu berjalan lancar pada hardware (handset smartphone android dan di komputer). Selain itu kebutuan perangkat lunak pendukung juga harus tersedia demi kelancaran tahap implementasi program.

Dalam proses mengimplementasikan ini ada beberapa langkah-langkah yang dilakukan, yaitu: 
a. Menuliskan kode program (coding), tahap ini dilakukan dengan menggunakan program pngembangan aplikasi android, yaitu Android Developer Tools (ADT), Android SDK (Software Development Kit), Notepad++, dan XAMPPLITE.

b. Melakukan proses pemaketan dengan menggunakan fasilitas yang disediakan oleh Android SDK.

c. Menguji program dengan menggunakan handset smartphone android dan di web browser. Serta melakukan debugging atau perbaikan program apabila diperlukan.

Tahap terakhir pada fase ini adalah uji aplikasi secara blackbox yaitu dengan mengetahui fungsi yang ditentukan serta dimana produk dirancang untuk melakukan sesuatu, pengujiannya dapat dilakukan untuk memperlihatkan bahwa fungsi beroperasi sepenuhnya. Disini penulis akan melakukan pengujian aplikasi berdasarkan use case yang dirancang di fase workshop design dan Untuk sisi native application akan diinstal pada beberapa handset android dari berbagai merek dan beberapa level operating system android.

\section{Kesimpulan}

Dari pembahasan yang sudah diuraikan, dapat disimpulkan bahwa:

1. Aplikasi sistem monitoring pemberian obat bagi pasien, merupakan aplikasi yang dirancang pada smartphone android dan web application.

2. Aplikasi ini dapat membantu perawat dalam mengontrol pemberian obat pasien.

3. Aplikasi ini mampu membantu meringankan kerja perawat dalam pelayanan kepada pasien dan mengurangi kemungkinan kesalahan yang terjadi pada pemberian obat bagi pasien.

\section{Referensi}

[1] M. Sadikin and I. Wasito, "Translation and classification algorithm of FDA-Drugs to DOEN2011 class therapy to estimate drug-drug interaction," in The 2nd International
Conference on Information Systems for Business Competitiveness, 2013.

[2] M. Sadikin, M. I. Fanany, and T. Basaruddin, "A New Data Representation Based on Training Data Characteristics to Extract Drug Name Entity in Medical Text," Comput. Intell. Neurosci., vol. 2016, 2016

[3] F. Masya, H. Prastiawan, and S. Mubaroq, "Application Design to Diagnosis of Bone Fracture using Forward Chaining Method," Int. Res. J. Comput. Sci., vol. 3, no. 9, 2016.

[4] A. Nugroho, Rational Rose untuk Pemodelan Berorientasi Objek. Informatika, 2005.

[5] H. W. Pramana, Aplikasi Manajemen Perekrutan Berbasis Access. Jakarta: PT Elex Media Komputindo, 2005.

[6] Whitten, Metode Desain dan Analisis Sistem. Jakarta: Andi, 2004.

[7] R. S. Pressman, Software Engineering $A$ Practioner's Approach, 7th Editio. New York: The McGraw-Hill Companies, 2010.

[8] Kendall, K.E. and J. . Kendall, System Analisis and Design 7th Edition. New Jersey: Prentice Hall, 2008. 